Kredo 4 (2020)
KREDO: Jurnal Ilmiah Bahasa dan Sastra
Terakreditasi Sinta 4 berdasarkan Keputusan Direktorat
Jenderal Penguatan Riset dan Pengembangan,
Kementerian Riset, Teknologi dan Pendidikan Tinggi
Republik Indonesia
Nomor: 23/E/KPT/2019. 08 Agustus 2019
https://jurnal.umk.ac.id/index.php/kredo/index

\title{
ANALISIS STRUKTUR, FUNGSI, DAN NILAI PADA FOLKLOR NAWANGSIH UNTUK PENDIDIKAN KARAKTER SISWA SEKOLAH DASAR
}

\author{
Anisatun Hidayatullah', Su'ad ${ }^{2}$, Mohammad Kanzunnudin ${ }^{3}$ \\ anisatunh2010@gmail.com
}

Universitas Muria Kudus, Indonesia

Info Artikel
Sejarah Artikel
Diterima
8 Juni 2020
Disetujui
21 September 2020
Dipublikasikan
28 Oktober 2020

Keywords

Structure, function, character value, Nawangsih folklore, Elementary school children's education

Kata Kunci

Struktur, fungsi, nilai karakter, folklor Nawangsih, pendidikan siswa sekolah dasar

\section{:}

The research on Nawangsih folklore aims to describe the structure, function and character values of Nawangsih folklore. This research uses a qualitative approach. Data collection techniques by observation, in-depth interviews, photography, recording, and transcription. The results show that Nawangsih folklore has a character structure, function, and value. The structure of Nawangsih folklore based on Propp theory found that the structure of the story is a prohibition uttered to heroes (II), prohibitions violated by heroes (III), criminals harass or injure family members (VIII), heroes are told to leave (IX), heroes leave home (XI ), the hero is tested (XII), the hero has a miracle (XIV), the hero is guided to the place of punishment $(X V)$, the hero and the villain engage in battle (XVI), the hero goes home $(X X)$, the heavy task is carried out by the hero : $\quad(X X V)$, completed tasks (XXVI), and known heroes (XXVII). Nawangsih folklore has a function (1) as education, (2) as an endorsement of community norms, (3) as character building, (4) as a community cultural value, and (5) as a means of community communication. Then, the character values found in Nawangsih folklore are religious characters, nationalism characters, independent characters, mutual cooperation characters, and integrity characters.

\section{Abstrak}

Penelitian ini bertujuan untuk mendeskripsikan struktur, fungsi, dan nilai cerita rakyat Nawangsih. Penelitian ini merupakan penelitian kualitatif. Teknik pengumpulan data dengan observasi, wawancara mendalam, pemotretan, pencatatan, dan transkripsi. Hasilnya menunjukkan bahwa cerita rakyat Nawangsih memiliki struktur, fungsi, dan nilai karakter. Struktur cerita rakyat Nawangsih berdasarkan teori Propp ditemukan struktur cerita yaitu satu larangan diucapkan kepada pahlawan (II), larangan dilanggar oleh pahlawan (III), penjahat melecehkan atau melukai anggota keluarga (VIII), pahlawan disuruh pergi (IX), pahlawan meninggalkan rumah (XI), pahlawan diuji (XII), pahlawan itu memiliki keajaiban (XIV), pahlawan dipandu ke tempat hukuman (XV), pahlawan dan penjahat terlibat dalam pertempuran (XVI), pahlawan pulang (XX), tugas berat dilakukan oleh pahlawan (XXV), tugas diselesaikan (XXVI), dan pahlawan yang dikenal (XXVII). Cerita rakyat Nawangsih memiliki fungsi (1) sebagai pendidikan, (2) sebagai pengesahan norma masyarakat, (3) sebagai pembentukan karakter , (4) sebagai nilai budaya masyarakat, dan (5) sebagai alat komunikasi masyarakat. Kemudian, nilai karakter yang ditemukan dalam cerita rakyat Nawangsih berupa karakter religius, karakter nasionalisme, karakter mandiri, karakter gotong royong, dan karakter integritas.

\section{PENDAHULUAN}

Indonesia merupakan negara kepulauan yang luas serta memiliki budaya yang beragam. Budaya tersebut salah satunya adalah cerita rakyat yang berasal dari daerah tertentu. Folklor adalah salah satu sastra tradisional. Sastra tradisional adalah karya sastra yang paling berkembang di Indonesia (Faidah, 2018:127). Salah satu daerah di 148 | Jurnal Kredo Vol. 4 No. 1 Oktober 2020
Indonesia yang memiliki cerita rakyat adalah Kudus. Kudus adalah kabupaten di Provinsi Jawa Tengah yang paling kecil wilayahnya (Dinas Pariwisata dan Kebudayaan, 2005). Walaupun begitu, Kudus mempunyai cerita rakyat yang jumlahnya banyak. Cerita rakyat adalah cerita yang berkembang di rakyat atau masyarakat (Maryatin, 2018:22). Folklor mempunyai hubungan dengan komunitas atau masyarakat suatu daerah di berbagai 


Kredo 4 (2020)
KREDO: Jurnal Ilmiah Bahasa dan Sastra
Terakreditasi Sinta 4 berdasarkan Keputusan Direktorat
Jenderal Penguatan Riset dan Pengembangan,
Kementerian Riset, Teknologi dan Pendidikan Tinggi
Republik Indonesia
Nomor: 23/E/KPT/2019. 08 Agustus 2019
https://jurnal.umk.ac.id/index.php/kredo/index

bidang kehidupan (Kanzunnudin, 2020:236). Salah satu cerita rakyat yang berjudul "Nawangsih". Cerita rakyat "Nawangsih" ini merupakan cerita rakyat berbentuk cerita prosa rakyat. Cerita rakyat ini berkembang di Desa Kandangmas, Kecamatan Dawe, Kabupaten Kudus, Jawa Tengah.

Berdasarkan observasi yang peneliti lakukan, ternyata wujud cerita rakyat yang berjudul "Nawangsih" saat ini semakin kurang dipedulikan. Misalnya, masyarakat Desa Kandangmas saat diminta menjelaskan mengenai bagaimana cerita rakyat tersebut, sebagian besar tidak memahami detailnya. Sekarang, anak-anak Desa Kandangmas tertarik dengan permainan yang ada di gadget serta film animasi yang berisi cerita-cerita negara lain. Cerita rakyat ini oleh orangtua dan tokoh masyarakat enggan diceritakan kepada anak-anak. Karena mereka beranggapan bahwa saat ini kebutuhan hidup semakin banyak dan berat, sehingga tidak ada waktu untuk bercerita cerita rakyat kepada anak-anak.

Kandungan cerita rakyat yang berjudul "Nawangsih" yang berasal dari Desa Kandangmas, Kecamatan Dawe, Kabupaten Kudus, Jawa Tengah ini bisa kita pahami untuk pendidikan anak sekolah dasar, yaitu dengan cara menganalisis struktur, fungsi, dan nilai karakter. Tiga aspek ini bisa untuk menjaga dan melestarikan cerita rakyat yang berjudul "Nawangsih".

Folklor penting bagi pendidikan siswa sekolah dasar. Hal ini agar siswa sekolah dasar memiliki pengetahuan luas betapa uniknya folklor. Folklor memiliki alur yang tidak ditemui pada kehidupan nyata siswa sekolah dasar. Berdasarkan pada problematika tersebut, maka peneliti meneliti cerita rakyat "Nawangsih" berdasarkan sudut pandang struktur, fungsi, dan nilai karakternya. Adapun permasalahan dalam penelitian ini, yakni (1) bagaimana struktur cerita rakyat Nawangsih, (2) apa saja fungsi cerita rakyat Nawangsih, dan (3) untuk pendidikan anak sekolah dasar, nilai karakter apa dalam cerita rakyat Nawangsih. Adapun penelitian ini bertujuan untuk mendeskripsikan struktur, fungsi, dan nilai karakter cerita rakyat Nawangsih untuk pendidikan anak sekolah dasar.

\section{KAJIAN TEORI}

\section{Esensi Cerita Rakyat}

Folklor atau cerita rakyat merupakan kebudayaan yang dihasilkan oleh masyarakat atau rakyat pada masa lampau dan disebarkan secara turun temurun kepada generasi penerusnya. Kanzunnudin (2017:3) menjelaskan bahwa folklor adalah karya masyarakat berupa lisan atau tulisan yang sampaikan kepada keturunannya serta berisi nilai kehidupan. Folklor adalah karya rakyat yang berisi nilai budaya daerah tertentu (Rahayu, 2018:12).

Folklor adalah budaya nontulis yang terdapat di kehidupan masyarakat serta mengandung amanat-amanat yang bisa dijadikan panutan (Indiarti, 2017:27). Gusal (2015:121) menyatakan bahwa cerita rakyat adalah karya suatu komunitas di masa lampau yang disebarkan secara lisan ke generasi berikutnya.

Folklor adalah outcome masyarakat di wilayah tertentu berdasarkan budaya yang ada (Hardiyanti, 2018:314). Sejalan 


Kredo 4 (2020)
KREDO: Jurnal Ilmiah Bahasa dan Sastra
Terakreditasi Sinta 4 berdasarkan Keputusan Direktorat
Jenderal Penguatan Riset dan Pengembangan,
Kementerian Riset, Teknologi dan Pendidikan Tinggi
Republik Indonesia
Nomor: 23/E/KPT/2019. 08 Agustus 2019
https://jurnal.umk.ac.id/index.php/kredo/index

dengan itu, Djamaris dalam Ramitha et.al. (2015:49) mengemukakan folklor adalah cerita di masyarakat suatu wilayah tertentu dan diturunkan kepada generasi selanjutnya. Rahmat (2019:86) menyatakan bahwa cerita rakyat adalah sastra daerah yang disampaikan dengan bahasa setempat sejak sebelum adanya bahasa-bahasa tulis.

Berdasarkan pendapat tersebut, dapat dipahami bahwa folkor adalah cerita lisan berdasarkan budaya daerah tertentu, diturunkan oleh leluhur pada zaman dahulu kepada generasi penerusnya.

\section{Cerita Prosa Rakyat}

Folklor "Nawangsih" merupakan cerita rakyat yang berbentuk cerita prosa rakyat yang ada di Desa Kandangmas Kecamatan Dawe Kabupaten Kudus (Peneliti). Mengenai bentuk cerita rakyat, Brunvand (dalam Danandjaja, 1994:21-22) membagi menjadi tiga kelompok besar. Pertama, folklor lisan adalah folklor yang bentuknya murni lisan. Bentuk-bentuk cerita rakyat ini yaitu (a) pertanyaan tradisional, seperti teka-teki; (b) bahasa rakyat (julukan, logat, dan titel kebangsawanan); (c) ungkapan tradisional (pepatah, peribahasa, dan pemeo); (d) cerita prosa rakyat, seperti legenda, mite, dan dongeng; (e) puisi rakyat, seperti syair, gurindam, dan pantun; dan (f) nyanyian rakyat.

Kedua, cerita rakyat sebagian lisan adalah cerita rakyat yang bentuknya perpaduan unsur bukan lisan dan unsur lisan. Misalnya takhayul atau kepercayaan rakyat yang terdiri atas gerak isyarat yang dianggap memiliki makna gaib ditambah dengan pernyataan yang bersifat lisan. Bentuk lainnya seperti tari rakyat, permainan rakyat, adat-istiadat, teater rakyat, pesta rakyat, dan upacara.

Ketiga, cerita rakyat bukan lisan adalah cerita rakyat yang bentuknya bukan lisan meskipun cara pembuatannya disampaikan dari mulut ke mulut. Bentuk folklor ini yaitu bukan material dan material. Bentuk folklor bukan material seperti bunyi isyarat untuk komunikasi rakyat (kentongan), gerak isyarat tradisional, dan musik rakyat. Adapun cerita rakyat material seperti arsitektur rakyat (bentuk lumbung padi dan bentuk rumah adat), obat tradisional, busana adat dan perhiasan, kerajinan tangan, obat-obatan tradisional, serta makanan dan minuman rakyat.

Hutomo (dalam Cahyaningsih, 2017:107) menyatakan bahwa folklor memiliki fitur (1) oral (lisan), (2) sifatnya tradisional, (3) keberadaannya sering memiliki banyak versi, (4) selalu tanpa pengarang atau penulis, dan (5) cenderung mempunyai formula atau formulanya jelas. Berdasarkan pemahaman tersebut menandaskan bahwa folklor "Nawangsih"adalah folklor lisan berbentuk cerita prosa rakyat.

\section{Struktur}

Struktur merupakan aspek-aspek yang saling terhubung dan mengikat satu sama lain serta menimbulkan makna yang menyeluruh. Mengenai struktur, Endraswara (2009:114) mengatakan bahwa struktur adalah suatu bangun yang abstrak yang bagian-bagiannya terikat satu sama lain. Struktur adalah rangkaian elemen atau aspek atau unsur

\footnotetext{
150 | Jurnal Kredo

Vol. 4 No. 1 Oktober 2020
} 


Kredo 4 (2020)
KREDO: Jurnal Ilmiah Bahasa dan Sastra
Terakreditasi Sinta 4 berdasarkan Keputusan Direktorat
Jenderal Penguatan Riset dan Pengembangan,
Kementerian Riset, Teknologi dan Pendidikan Tinggi
Republik Indonesia
Nomor: 23/E/KPT/2019. 08 Agustus 2019
https://jurnal.umk.ac.id/index.php/kredo/index

yang ada dalam hubungan yang sama pada kegiatan manusia (Mujianto, 2010:48). Lalu, Permana (2015:175) mendefinisikan bahwa struktur adalah kesatuan konstruksi utuh yang saling berhubungan.

Berdasarkan penjelasan Suhaimi (2014:2) menyatakan bahwa struktur adalah elemen yang saling mengikat satu sama lain untuk memberikan arti secara menyeluruh. Setyosari (2010:148) juga mengemukakan bahwa struktur adalah hubungan antara variabel dalam suatu penelitian.

Berdasarkan beberapa pendapat tersebut, peneliti menyimpulkan bahwa struktur adalah unsur-unsur yang terikat dan saling berhubungan serta menimbulkan makna yang menyeluruh.

Cerita rakyat adalah karya sastra yang mempunyai struktur berbeda dengan karya sastra pada umumnya. Folklor merupakan cerita yang dihasilkan oleh masyarakat atau rakyat dan ditularkan dari mulut ke mulut. Roysa (2017:18) menjelaskan bahwa analisis struktur adalah menganalisis keterhubungan struktur yang ada dalam karya sastra, yang menghasilkan makna yang menyeluruh. Maka dari itu, untuk menganalisis cerita rakyat harus memahami multilevel makna, karena makna cerita rakyat bukan hanya sebatas makna denotatif. Memahami struktur cerita (struktur naratifnya atau motif cerita) merupakan langkah pertama untuk memahami folklor.

Folklor menggambarkan fenomena yang terjadi di suatu wilayah. Dari segi strukturalisme, folklor dimaksudkan memudahkan pemahaman dari aspek tata bahasa yang dipakai. Di tahun 60-an di Eropa Barat dan Amerika ada teori yang terkenal yaitu teori Vladimir Propp. Vladimir Propp merupakan tokoh penemu analisis folklor berdasarkan strukturalistik. Vladimir Propp membedah folklor Rusia menurut struktur atau aspek-aspeknya serta seperti apa keterkaitannya. Vladimir Propp mengklasifikasikan 31 fungsi (motif cerita) yakni mengaitkan segala kejadian serta tindakan yang tidak sama namun memiliki makna tidak berbeda. Hal ini berarti bahwa setiap cerita rakyat tidak harus memiliki 31 fungsi (motif cerita), karena ada cerita rakyat yang memiliki fungsi tidak maksimal.

Propp menjelaskan (dalam Maulina, 2014:108-109); Lestari, 2015:143-144; Hakim, 2015:520-521) terdapat 31 fungsi (motif cerita) yang menunjukkan perbuatan tokoh dan bahasa naratif. 31 fungsi (motif cerita) yaitu (1) salah satu anggota keluarga pergi dari rumah, (2) satu larangan diucapkan kepada pahlawan, (3) larangan dilanggar, (4) penjahat mencoba mengintai, (5) penjahat menerima informasi tentang korbannya, (6) penjahat mencoba memperdaya korbannya dengan tujuan mempunyai dirinya atau kepunyaannya, (7) korban terperangkap dan tanpa disadari menolong musuhnya, (8) penjahat mengganggu atau mencederai salah satu anggota keluarga, (9) kecelakaan atau kekurangan diumumkan, pahlawan diminta atau diperintah, diperbolehkan pergi atau diutus, (10) pencuri menyetujui atau memutuskan untuk membalas, (11) pahlawan meninggalkan rumah, (12) pahlawan diuji dan diserang yang mempersiapkannya, pahlawan menerima sesuatu alat magis atau pembantu, (13) pahlawan membalas dendam kepada 


Kredo 4 (2020)
KREDO: Jurnal Ilmiah Bahasa dan Sastra
Terakreditasi Sinta 4 berdasarkan Keputusan Direktorat
Jenderal Penguatan Riset dan Pengembangan,
Kementerian Riset, Teknologi dan Pendidikan Tinggi
Republik Indonesia
Nomor: 23/E/KPT/2019. 08 Agustus 2019
https://jurnal.umk.ac.id/index.php/kredo/index

tindakan calon pemberi-pemberi, (14) pahlawan memperoleh agen sakti, (15) dipindahkan atau dibimbing ke tempattempat terdapatnya objek yang dicari, (16) pahlawan dan penjahat terlibat dalam pertarungan, (17) pahlawan ditandai, (18) penjahat dikalahkan, (19) kecelakaan atau kekurangan awal diatasi, (20) pahlawan pulang, (21) pahlawan dikejar, (22) pahlawan diselamatkan, (23) pahlawan yang tidak dikenali tiba di negerinya atau negeri lain, (24) pahlawan palsu memberikan tuntunan palsu, (25) suatu tugas yang sulit diberikan kepada pahlawan, (26) tugas diselesaikan, (27) pahlawan dikenali, (28) pahlawan palsu atau penjahat terungkap, (29) pahlawan diberikan wujud baru, (30) penjahat palsu dihukum, dan (31) pahlawan menikah dan menaiki tahta.

\section{Fungsi}

Ramadhan et.al. (2016:2) menyatakan bahwa fungsi cerita rakyat yaitu sebagai amanat atau pesan bagi pendengarnya. Sajaril (2019:71) berpendapat bahwa fungsi cerita rakyat adalah memantapkan identitas dan integritas sosial. Lalu, Ani (2019:40) mengemukakan folklor memiliki fungsi seperti (1) untuk hiburan, (2) untuk alat pengesahan, (3) untuk alat pendidikan, (4) untuk alat pemaksa dan pengawas aturan masyarakat, (5) untuk senjata potensial di dalam memperjuangkan kelas sosial, (6) untuk sarana kritik sosial, (7) meningkatkan perasaan solidaritas suatu komunitas, dan (8) memberikan suatu pelarian yang menyenangkan dari kenyataan.

Berdasarkan beberapa pendapat tersebut, dapat disimpulkan bahwa fungsi cerita rakyat mencakup (1) sebagai pendidikan, (2) sebagai pengesahan norma masyarakat, (3) sebagai pembentukan karakter, (4) sebagai nilai budaya masyarakat, dan (5) sebagai alat komunikasi masyarakat.

\section{Nilai Karakter}

Character education atau moral berkaitan dengan perilaku. Character education berorientasi membentuk sikap batiniah sesorang supaya mempunyai refleks dalam bertindak. Tiga aspek yang menunjukkan karakter individu yakni knowing the good (mengetahui kebaikan), loving the good (mencintai kebaikan), dan doing the good (melakukan kebaikan).

Samani et.al.

menjelaskan bahwa karakter adalah tindakan yang khas dari setiap individu dalam hidup dan bekerja sama dalam lingkungan keluarga, masyarakat, bangsa, dan negara. Berdasarkan Muslich (2011:94) mendefinisikan bahwa karakter adalah kualitas moral indvidu terhadap apapun yang ditemuinya. Karakter adalah perilaku stabil individu yang terbentuk dari kebiasaan berpadu dengan budaya, lingkungan, dan sebagainya (Kanzunnudin, 2012:199).

Benninga et.al.

(2003:19) menyatakan bahwa karakter di sekolah itu bagus. Hapsari (2013:2) berpendapat bahwa karakter bisa dimasukkan dalam pembelajaran dan teladan di luar kelas. Alim et.al. (2020:140) mengemukakan bahwa karakter saat ini memang menjadi bagian dari proses pembentukan moral siswa, bahkan karakter diharapkan menjadi fondasi utama bagi bangsa. Goodwin (2015:38) berpendapat ketika 


Kredo 4 (2020)
KREDO: Jurnal Ilmiah Bahasa dan Sastra
Terakreditasi Sinta 4 berdasarkan Keputusan Direktorat
Jenderal Penguatan Riset dan Pengembangan,
Kementerian Riset, Teknologi dan Pendidikan Tinggi
Republik Indonesia
Nomor: 23/E/KPT/2019. 08 Agustus 2019
https://jurnal.umk.ac.id/index.php/kredo/index

karakter diadu dengan kehangatan, karakter jelas merupakan pendorong yang lebih penting dari pembentukan kesan.

Karakter adalah serangkaian keadaan rohaniah individu dari Tuhan Yang Maha Esa (Saptono, 2011:8). Kesuma et.al. (2013:11) mendefinisikan bahwa karakter merupakan suatu nilai yang diimplementasikan dalam bentuk sikap atau tindakan. Bennett (1988:29) berpendapat bahwa karakter harus mulai dibentuk di rumah, dimulai pada tahuntahun awal masa kanak-kanak. Cohen et.al. (2012:356) ketika mempelajari karakter moral, kita fokus pada kecenderungan rasa bersalah daripada kecenderungan rasa malu karena rasa bersalah adalah emosi yang lebih moral daripada rasa malu, dalam hal itu terkait lebih kuat dengan perilaku etis.

Berdasarkan beberapa pendapat, dapat disimpulkan karakter adalah perbuatan sehari-hari individu yang relevan dengan budaya, agama, norma, hukum, adat istiadat, dan tata krama.

Pendidikan karakter memiliki tujuan yang baik, sehingga implementasinya harus optimal. Character education menurut Susanti (2013:482) memiliki tujuan memperbaiki mutu pendidikan satuan pendidikan yang relevan dengan standar kompetensi lulusan serta dapat diketahui dengan terbentuknya karakter siswa. Adapun Mulyasa (2013:9) menyatakan tujuan character education adalah untuk menjadikan siswa bisa mandiri dalam mengembangkan pengetahuannya, menganalisis nilai karakter yang diimplikasikan melalui tindakan di kehidupan sehari-hari.

Kesuma et.al. (2013:9) menyatakan character education bertujuan mereviu sikap siswa yang tidak relevan dengan nilai-nilai kehidupan yang dianggap penting sehingga menjadi kepribadian siswa yang khas, dan (2) mengkonstruksi komunikasi baik yakni dengan orang lain sebagai tanggungjawab pembangunan pendidikan karakter. Adapun Muttaqin (2018:105) berpendapat bahwa karakter untuk sekolah dasar mencakup integrasi karakter ke dalam kurikulum.

Berdasarkan beberapa pendapat, dapat dipahami character education memiliki tujuan membentuk probadi siswa yang bermartabat, mantap, dan baik dalam kehidupan sehari-hari.

Pendidikan karakter bangsa merupakan ujung tombak terwujudnya siswa yang baik dalam kehidupan seharihari dengan berpedoman pada nilai-nilai karakter. Nilai karakter berdasarkan Permendikbud Nomor 20 Tahun 2018 mencakup (1) religius, (2) nasionalisme, (3) mandiri, (4) gotong royong, dan (5) integritas. Religius merupakan perilaku melakukan perintah serta meninggalkan larangan agama yang dipeluk, toleransi terhadap pelaksanaan ibadah agama dan kepercayaan lain, damai dan hidup rukun dengan pemeluk agama lain. Tiga dimensi nilai karakter religius yakni hubungan individu dengan Tuhan, individu dengan sesame, dan individu dengan alam semesta (lingkungan). Subnilai religius yaitu beriman dan bertaqwa, disiplin ibadah, cinta damai, toleransi, menghargai perbedaan agama dan kepercayaan, persahabatan, ketulusan, bersih, antibuli dan kekerasan, tidak memaksakan kehendak, memanfaatkan lingkungan dengan bijak, melindungi yang kecil dan tersisih. 


\begin{tabular}{|c|c|c|}
\hline & $\begin{array}{c}\text { Kredo } 4(2020) \\
\text { KREDO: Jurnal Ilmiah Bahasa dan Sastra } \\
\text { Terakreditasi Sinta } 4 \text { berdasarkan Keputusan Direktorat } \\
\text { Jenderal Penguatan Riset dan Pengembangan, } \\
\text { Kementerian Riset, Teknologi dan Pendidikan Tinggi } \\
\text { Republik Indonesia } \\
\text { Nomor: } 23 / \text { E/KPT/2019. 08 Agustus 2019 } \\
\text { https://jurnal.umk.ac.id/index.php/kredo/index }\end{array}$ & $\begin{aligned} \mathrm{KREDO} \\
\square \\
\square \\
\square \\
\square\end{aligned}$ \\
\hline
\end{tabular}

Nasionalisme adalah cara bertindak dan berpikir yang menunjukkan penghargaan yang tinggi, kepedulian dan kesetiaan terhadap politik bangsa, ekonomi, bahasa, sosial, budaya, lingkungan fisik, mendahulukan hajat bangsa dan negara daripada hajat pribadi. Nasionalisme subnilainya yaitu penghargaan budaya asli, rela berkorban, unggul dan berprestasi, menjaga lingkungan, menjaga dan melestarikan kekayaan budaya bangsa, disiplin, taat hukum, cinta tanah air, menghormati keragaman agama, suku, dan budaya, menghargai kebhinnekaan, semangat kebangsaan.

Mandiri merupakan perilaku tidak bergantung pada orang lain dan memakai seluruh pikiran, tenaga, waktu untuk mewujudkan cita-cita, mimpi, dan harapan. Subnilai mandiri yaitu tangguh, etos kerja (kerja keras), profesional, keberanian, tahan banting, kreatif, daya juang, dan menjadi pembelajar sepanjang hayat.

Gotong royong adalah perilaku bahu membahu dalam menyelesaikan problematika dan kendala yang ada, menjalin persahabatan dan komunikasi. Gotong royong memiliki subnilai yakni kerja sama, menghargai, empati, musyawarah mufakat, inkusif, anti diskriminasi, sikap kerelawanan, anti kekerasan, solidaritas, dan komitmen atas keputusan bersama.

Integritas adalah mempunyai kesetiaan dan komitmen pada integritas moral dan kemanusiaan, nilai yang berdasarkan selalu dipercaya dalam pekerjaan, perilaku, dan perkataan. Karakter integritas mencakup aktif terlibat dalam kehidupan sosial, melalui konsistensi perkataan dan perbuatan yang berdasarkan kebenaran, tanggung jawab sebagai warga negara. Subnilai integritas yaitu keadilan, kejujuran, keteladanan, cinta pada kebenaran, anti korupsi, komitmen moral, setia, tanggung jawab, dan menghargai martabat individu (terutama penyandang disabilitas).

\section{Pendidikan Anak Sekolah Dasar}

Pendidikan di sekolah dasar adalah usaha untuk membentuk anak yang bertaqwa kepada Tuhan Yang Maha Esa, tanggung jawab, terbuka, jujur, cinta tanah air, rela berkorban, serta bisa menyelesaikan problematika dalam kehidupan sehari-hari.

Pendidikan tingkat dasar yang dilalui anak-anak usia 7 hingga 13 tahun sebagai pendidikan dasar yang dikembangkan sesuai dengan potensi daerah atau ciri khas daerah, satuan pendidikan, sosial budaya masyarakat setempat bagi siswa. Implementasi pendidikan di sekolah dasar menjadi lembaga yang diatur dan diawasi oleh pemerintah di bidang pendidikan formal dengan jangka waktu 6 tahun, berawal kelas I, berakhir di kelas VI untuk anak atau siswa Indonesia. Siswa sekolah dasar dididik bermacam-macam bidang studi yang harus dikuasai seluruhnya (Nazarudin, 2013).

Pendidikan di sekolah dasar ini diselenggarakan dengan hati-hati dan tanggung jawab penuh, sebab sekolah dasar adalah tempat pertama anak atau siswa dibimbing, dididik, dan diarahkan dalam pembentukan karakter. Menanamkan keimanan terhadap Tuhan Yang Maha Esa sesuai dengan kepercayaan dan agama yang dipilihnya, tujuannya agar bisa menanamkan sikap 


Kredo 4 (2020)
KREDO: Jurnal Ilmiah Bahasa dan Sastra
Terakreditasi Sinta 4 berdasarkan Keputusan Direktorat
Jenderal Penguatan Riset dan Pengembangan,
Kementerian Riset, Teknologi dan Pendidikan Tinggi
Republik Indonesia
Nomor: 23/E/KPT/2019. 08 Agustus 2019
https://jurnal.umk.ac.id/index.php/kredo/index

yang sopan, toleransi, berakhlak, dan santun antarumat manusia.

Karakteristik umum pendidikan sekolah dasar dinyatakan oleh Gelis (2017) yaitu (1) kemampuan berkomunikasi adalah dapat mengomunikasikan sesuatu, baik gagasan sendiri maupun berita yang diperoleh dari sumber lain, kepada penyimak atau lawan bicara; (2) kemelekwacaan (literacy), pendidikan anak sekolah dasar diarahkan pada pembentukan kemelekwacaan bukan hanya kemampuan akademik. Pemahaman anak sekolah dasar mengenai macam-macam ide atau fenomena di lingkungannya untuk menyesuaikan perbuatan dengan kehidupan; (3) kemampuan bernalar (reasoning) adalah memakai bukti-bukti dan logika secara sistematis dan konsistensi untuk sampai pada simpulan. Pendidikan dasar diarahkan untuk mengembangkan kemampuan anak berpikir logis sehingga keterampilan bernalarnya meningkat; (4) kemampuan memecahkan problematika (problem solving) meliputi merasakan problematika, mengidentifikasi problematika, mencari informasi untuk memecahkan problematika, mencari alternatif pemecahan problematika, dan memilih alternatif yang sesuai dengan problematika.

Nazarudin (2013) mengemukakan karakteristik khusus pendidikan sekolah dasar yaitu (1) guru sekolah dasar adalah guru kelas, diwajibkan bisa mendidik siswa dengan sepenuh hati, mengajarkan seluruh mata pelajaran, kecuali Agama dan Penjaskes. Guru kelas di sekolah dasar mengajar dari jam pertama hingga terakhir. Bertanggung jawab penuh terhadap kelas yang diajar, mulai dari administrasi kelas, administrasi sekolah, kehadiran siswa, hingga pemberian rapor; (2) siswa sekolah dasar berusia 7 hingga 13 tahun. Berdasarkan usia tersebut, terdapat perbedaan dari segi mental maupun fisik dengan siswa SMP atau SMA. Anak sekolah dasar merupakan tahap operasi konkret dan awal operasi abstrak. Masih memandang segala sesuatu secara umum (holistik); (3) kurikulum sekolah dasar merupakan alat penting dalam satuan pendidikan dan bagian dari kurikulum pendidikan dasar. Sekolah dasar ditempuh selama 6 tahun yang dimulai dari kelas I dan diakhiri di kelas VI. Memakai sistem semester, kelas I dan II durasi satu jam pelajaran selama 30 menit untuk kelas I dan II, lalu selama 35 menit untuk kelas III hingga VI. Terdapat 9 mata pelajaran termasuk muatan lokal di sekolah dasar; (4) pembelajaran di sekolah dasar adalah aktivitas manipulatif, pembelajaran terpadu, dan aktivitas konkret, merupakan gambaran dari tingkat perkembangan anak sekolah dasar. Menyuguhkan latihan atau pengalaman belajar yang relevan dengan tingkat perkembangan anak dinamakan Development Appropriate Practice (DAP); (5) gedung dan peralatan pembelajaran sekolah dasar beragam macamnya. Gedung sekolah dasar umumnya memiliki 6 ruang kelas, 1 ruang kantor guru, 1 ruang kantor kepala sekolah, 1 ruang perpustakaan, 1 ruang musholla, 1 ruang laboratorium bahasa, 1 ruang dapur, dan lapangan. Peralatan sekolah dasar sesuai dengan kebutuhan satuan pendidikan.

Berdasarkan beberapa pendapat tersebut, bisa dipahami pendidikan 


Kredo 4 (2020)
KREDO: Jurnal Ilmiah Bahasa dan Sastra
Terakreditasi Sinta 4 berdasarkan Keputusan Direktorat
Jenderal Penguatan Riset dan Pengembangan,
Kementerian Riset, Teknologi dan Pendidikan Tinggi
Republik Indonesia
Nomor: 23/E/KPT/2019. 08 Agustus 2019
https://jurnal.umk.ac.id/index.php/kredo/index

sekolah dasar karakteristiknya yaitu karakteristik umum dan khusus. Karakteristik umum mencakup kemampuan komunikasi, kemelekwacaan (literacy), keterampilan bernalar (reasoning), dan keterampilan menyelesaikan problematika (problem solving). Karakteristik khusus meliputi (1) guru; (2) siswa; (3) kurikulum satuan pendidikan; (4) pembelajaran (perencanaan, pelaksanaan, dan evaluasi); dan (5) gedung (bangunan sekolah) dan alat bantu pembelajaran.

\section{Implementasi Nilai Karakter pada Siswa Sekolah Dasar}

Pentingnya implementasi nilai karakter pada siswa sekolah dasar guna penanaman serta pembentukan karakter siswa sekolah dasar serta dapat dijadikan dasar membentuk bangsa yang bertaqwa, mantap, serta unggul di waktu mendatang. Maunah (2015:94-95) menyatakan bahwa aplikasi pendidikan karakter bisa dengan teknik tematik. Implementasinya melalui (1) pembuatan RPP dan silabus (perencanaan pendidikan karakter); (2) pembelajaran (aplikasi pendidikan karakter); dan (3) penilaian dan refleksi implementasi pendidikan karakter. Murniyetti (2016:159-162) menjelaskan bahwa pola implementasi pendidikan karakter siswa sekolah dasar meliputi (1) dengan tata tertib sekolah, merupakan cara tepat dalam menanamkan nilai karakter; (2) dengan materi pembelajaran, 5 nilai karakter telah menyatu dalam materi pembelajaran; (3) dengan ajang penghargaan siswa berprestasi, siswa sekolah dasar semakin semangat, jujur, pantang menyerah, dan sungguhsungguh dalam belajar; (4) melalui lomba sains antarsiswa; (5) melalui kegiatan pramuka; (6) dengan memperingati hari-hari besar nasional; (7) melalui kelas seni; dan (8) melalui bimbingan kerohanian dan praktik ibadah harian.

Berdasarkan beberapa pendapat tersebut, dapat dimengerti aplikasi pendidikan karakter siswa sekolah dasar bisa dilaksanakan dalam pembelajaran, di rumah, di sekolah, dan di masyarakat. Pembelajaran bisa dihubungkan langsung dengan pendidikan karakter.

\section{METODE PENELITIAN}

Penelitian ini berbentuk kualitatif yang tidak mengutamakan pada angkaangka. Penelitian kualitatif menurut Rubiyanto (2011:59) adalah metode penelitian yang datanya berupa non teks dari partisipan yang dilihat/didengar atau kata-kata tertulis. Peneliti ke tempat penelitian atau lapangan, melaksanakan pengamatan, instrumennya dirinya sendiri, wawancara menyesuaikan tempat penelitian atau lapangan. Sugiyono (2016:15) juga berpendapat instrumennya adalah peneliti, mengobservasi dan mewawancarai objek penelitian serta memfokuskan makna daripada generalisasi merupakan sebutan dari penelitian kualitatif.

Untuk menguji keabsahan data dalam penelitian ini, peneliti menggunakan metode triangulasi. Triangulasi merupakan metode pemeriksaan atau pengecekan keabsahan data dengan memanfaatkan berbagai sumber, berbagai cara, dan berbagai waktu. Hal ini dilakukan untuk keperluan pengecekan dan pembanding terhadap data. Dalam implementasinya, 


Kredo 4 (2020)
KREDO: Jurnal Ilmiah Bahasa dan Sastra
Terakreditasi Sinta 4 berdasarkan Keputusan Direktorat
Jenderal Penguatan Riset dan Pengembangan,
Kementerian Riset, Teknologi dan Pendidikan Tinggi
Republik Indonesia
Nomor: 23/E/KPT/2019. 08 Agustus 2019
https://jurnal.umk.ac.id/index.php/kredo/index

peneliti melakukan triangulasi narasumber.

Penelitian ini merupakan penelitian kualitatif. Tujuannya adalah untuk melukiskan peristiwa, kondisi, serta apapun yang berhubungan dengan dibutuhkan dalam penelitian (Setyosari, 2010:33). Penelitian kualitatif memiliki tujuan menggambarkan secara runtut karakteristik objek yang diteliti secara tepat (Rubiyanto, 2011:42). Emzir (2011:174) menyatakan penelitian kualitatif bertujuan mengungkapkan apapun yang terjadi dalam penelitian melalui kata-kata yang rinci. Teknik observasi data yang digunakan dalam penelitian ini meliputi observasi, wawancara mendalam, pemotretan, pencatatan, dan transkripsi merupakan teknik pengumpulan data yang digunakan dalam penelitian ini.

\section{HASIL DAN PEMBAHASAN}

\section{Struktur Folklor Nawangsih}

Propp menyatakan bahwa suatu cerita memiliki paling banyak 31 fungsi (motif cerita), namun, Propp juga menyatakan sebuah folklor tidak harus memiliki 31 fungsi (motif cerita). Analisis struktur folklor Nawangsih berdasarkan teori Propp ditemukan struktur cerita yaitu satu larangan diucapkan kepada pahlawan (II), larangan dilanggar oleh pahlawan (III), penjahat melecehkan atau melukai anggota keluarga (VIII), pahlawan disuruh pergi (IX), pahlawan meninggalkan rumah (XI), pahlawan diuji (XII), pahlawan itu memiliki keajaiban (XIV), pahlawan dipandu ke tempat hukuman (XV), pahlawan dan penjahat terlibat dalam pertempuran
(XVI), pahlawan pulang (XX), tugas berat dilakukan oleh pahlawan (XXV), tugas diselesaikan (XXVI), dan pahlawan yang dikenal (XXVII).

\section{Fungsi Cerita Rakyat Nawangsih}

Cerita rakyat Nawangsih berdasarkan hasil analisis memiliki fungsi. Fungsi yang meliputi (1) sebagai pendidikan, (2) sebagai pengesahan norma masyarakat, (3) sebagai pembentukan karakter, (4) sebagai nilai budaya masyarakat, dan (5) sebagai alat komunikasi masyarakat.

Pertama, fungsi (motif cerita) yang terkandung dalam folklor Nawangsih yaitu sebagai pendidikan, ditunjukkan Raden Bagus Rinangku sebagai murid Sunan Muria yang melaksanakan perintah gurunya. Kedua, fungsi yang terkandung dalam cerita rakyat Nawangsih yaitu sebagai pengesahan norma masyarakat, dilukiskan Nawangsih sebagai putri Sunan Muria yang harus menaati aturan agama dan orang tuanya, agar tidak terjadi hal buruk yang menimpanya.

Ketiga, fungsi yang terkandung dalam cerita rakyat Nawangsih yaitu sebagai pembentukan karakter, digambarkan bahwa Sunan Muria di setiap selesai solat Subuh mengaji bersama santrinya, kegiatan ini membangun karakter religius. Karakter mandiri ditunjukkan oleh Raden Bagus Rinangku yang mandiri dalam menjaga padi di Sawah Dukuh Masin.

Keempat, fungsi yang terkandung dalam cerita rakyat Nawangsih yaitu sebagai nilai budaya masyarakat, digambarkan bahwa Raden Bagus Rinangku sebagai murid baru Sunan Muria dikenalkan oleh beliau nilai-nilai 


Kredo 4 (2020)
KREDO: Jurnal Ilmiah Bahasa dan Sastra
Terakreditasi Sinta 4 berdasarkan Keputusan Direktorat
Jenderal Penguatan Riset dan Pengembangan,
Kementerian Riset, Teknologi dan Pendidikan Tinggi
Republik Indonesia
Nomor: 23/E/KPT/2019. 08 Agustus 2019
https://jurnal.umk.ac.id/index.php/kredo/index

budaya masyarakat sekitar. Kelima, fungsi yang terkandung dalam cerita rakyat Nawangsih yaitu sebagai alat komunikasi masyarakat, ditunjukkan bahwa komunikasi Raden Bagus Rinangku dengan Ki Surmojoyo baik dan sopan.

\section{Nilai Karakter Cerita Rakyat Nawangsih \\ Cerita rakyat Nawangsih} berdasarkan hasil analisis mengandung lima nilai karakter. Nilai karakter tersebut yaitu (1) religius, (2) nasionalisme, (3) mandiri, (4) gotong royong, dan (5) integritas.

Pertama, nilai karakter religius, memiliki subnilai mencakup (1) subnilai beriman dan bertaqwa, digambarkan dengan Sunan Muria mengaji bersama santrinya; (2) subnilai taat beribadah, digambarkan dengan Sunan Muria setiap selesai solat Subuh selalu mengaji bersama santrinya; (3) subnilai persahabatan, digambarkan adanya timbal balik Sunan Muria dengan pembantu dan santrinya; (4) subnilai ketulusan, digambarkan dengan ketulusan Sunan Muria mendidik muridnya dan Raden Bagus Rinangku yang melaksakan perintah Sunan Muria; (5) subnilai tidak mengeksploitasi alam, digambarkan dengan Raden Bagus Rinangku yang menjaga padi sawah Dukuh Masin dengan tanggung jawab; (6) subnilai gotong royong antarumat beragama, digambarkan dengan muridmuridnya Sunan Muria saling gotong royong; dan (7) subnilai percaya diri, digambarkan dengan Raden Bagus Rinanku yang percaya diri menjalankan perintah Sunan Muria untuk menjaga padi di sawah Dukuh Masin. Karakter religius juga digambarkan dengan Sunan Muria melarang putrinya Nawangsih untuk dekat dengan pria yang belum menjadi suaminya (Raden Bagus Rinangku).

Kedua, nilai karakter nasionalisme, memiliki subnilai mencakup (1) subnilai penghargaan budaya lokal, digambarkan dengan penduduk Dukuh Masin melakukan dan menjaga tradisi sedekah kubur atau seribu sempol dan buka luwur setiap tahunnya serta tradisi kirim ayam ingkung setiap memiliki hajat; (2) subnilai menjaga kekayaan budaya bangsa, digambarkan dengan masyarakat Dukuh Masin melaksanakan dan melestarikan tradisi sedekah kubur atau seribu sempol dan buka luwur setiap tahunnya serta tradisi kirim ayam ingkung setiap memiliki hajat; (3) subnilai menjaga lingkungan, subnilai ini ditunjukkan dengan masyarakat Dukuh Masin ikut menjaga makam Nawangsih dan Raden Bagus Rinangku agar tidak rusak; dan (4) subnilai rela berkorban, subnilai ini ditunjukkan dengan Nawangsih rela meninggal dunia demi orang yang dicintainya (Raden Bagus Rinangku) dan Raden Bagus Rinangku rela berkorban jauh dari pondok pesantren untuk melaksanakan perintah Sunan Muria. Karakter nasionalisme juga diungkapkan melalui semangat Raden Bagus Rinangku yang berasal dari Pandanaran yang melalukan perjalanan panjang untuk menuntut ilmu kepada Sunan Muria di Colo.

Ketiga, nilai karakter mandiri, memiliki subnilai (1) subnilai kerja keras, digambarkan Raden Bagus Rinangku yang menjaga padi di sawah Dukuh Masin hingga malam hari; (2) subnilai tangguh dan daya juang, 


Kredo 4 (2020)
KREDO: Jurnal Ilmiah Bahasa dan Sastra
Terakreditasi Sinta 4 berdasarkan Keputusan Direktorat
Jenderal Penguatan Riset dan Pengembangan,
Kementerian Riset, Teknologi dan Pendidikan Tinggi
Republik Indonesia
Nomor: 23/E/KPT/2019. 08 Agustus 2019
https://jurnal.umk.ac.id/index.php/kredo/index

digambarkan Raden Bagus Rinangku yang menjaga padi di sawah Dukuh Masin dengan tanggung jawab dan Sunan Muria yang mengajar santrinya dengan sungguh-sungguh; dan (3) subnilai keberanian, digambarkan Raden Bagus Rinangku yang berani melaksanakan perintah Sunan Muria untuk menjaga padi di sawah Dukuh Masin. Karakter berani juga ditunjukkan Sunan Muria yang menasihati putrinya untuk tidak dekat dengan pria yang belum menjadi suaminya.

Keempat, nilai karakter gotong royong, memiliki subnilai (1) subnilai bekerja sama, digambarkan masyarakat bersama-sama memakamkan jenazah Nawangsih dan Raden Bagus Rinangku di Dukuh Masin; dan (2) subnilai sikap kerelawanan, subnilai ini ditunjukkan dengan Ki Surmojoyo yang mengabdi kepada Sunan Muria dengan tulus.

Kelima, nilai karakter integritas, memiliki subnilai (1) subnilai kejujuran, digambarkan Nawangsih dan Raden Bagus Rinangku yang telah menjalani hubungan sebagai sepasang kekasih; dan (2) subnilai tanggungjawab dan keteladanan, digambarkan Sunan Muria yang mengajar muridnya dengan tanggungjawab dan keteladanan.

Folklor Nawangsih dalam menganalisis struktur naratifnya, peneliti menggunakan teori struktur naratif Propp (1926, 1997) Propp menyatakan setiap folklor mempunyai 31 fungsi naratif (motif cerita). Tetapi, adapula suatu folklor tidak memiliki semua 31 fungsi naratif (motif cerita). Folklor Nawangsih dianalisis dengan menggunakan 31 fungsi naratif (motif cerita). Data folklor Nawangsih didapatkan dengan wawancara keempat informan lalu disimpulkan menjadi satu data, yang dianalisis adalah sebanyak satu folklor.

Berpijak pada anaslisis struktur naratif (motif cerita) folklor Nawangsih, ada dua penemuan, yaitu (1) folklor Nawangsih tidak mempunyai 31 struktur naratif (motif cerita) dan (2) folklor Nawangsih memiliki 13 struktur naratif (motif cerita). Vansina (2014:107-113) mendefinisikan bahwa struktur naratif folklor adalah metode untuk menggambarkan isi. Berdasarkan teori struktur naratif (motif cerita) Propp (1926, 1997), folklor Nawangsih lebih menonjolkan isi bukan cara untuk menyampaikan isi. Hasan (2016:102) dalam penelitiannya menyatakan bahwa folklor Ikan Lompa tidak memiliki 31 fungsi struktur naratif (motif cerita) melainkan hanya 19.

Dari aspek analisis ditemukan 13 struktur naratif (motif cerita) folklor Nawangsih mencakup, yakni II (larangan) -III (pelanggaran) -VIII (kejahatan) -IX (peristiwa) -XI (keberangkatan) -XII (pemberi) -XIV (penerimaan alat sakti) $-\mathrm{XV}$ (perpindahan tempat) $-\mathrm{XVI}$ (pertarungan) $-\mathrm{XX}$ (kepulangan) $-\mathrm{XXV}$ (tugas berat) -XXVI (penyelesaian) XXVII (pahlawan).

Pola struktur naratif (motif cerita) folklor Nawangsih tersebut, jika digambarkan dalam alur cerita mengandung 9 aspek penting, yaitu (1) adanya larangan, (2) karena menginginkan sesuatu maka timbullah pelanggaran dan kejahatan, (3) keberangkatan tokoh untuk menyelesaikan masalah, (4) tokoh mendapatkan ujian dalam bertugas, (5) tokoh memiliki kesaktian untuk 


\begin{tabular}{|c|c|c|}
\hline & $\begin{array}{c}\text { Kredo } 4(2020) \\
\text { KREDO: Jurnal Ilmiah Bahasa dan Sastra } \\
\text { Terakreditasi Sinta } 4 \text { berdasarkan Keputusan Direktorat } \\
\text { Jenderal Penguatan Riset dan Pengembangan, } \\
\text { Kementerian Riset, Teknologi dan Pendidikan Tinggi } \\
\text { Republik Indonesia } \\
\text { Nomor: } 23 / \text { E/KPT/2019. 08 Agustus 2019 } \\
\text { https://jurnal.umk.ac.id/index.php/kredo/index }\end{array}$ & $\begin{aligned} \mathrm{KREDO} \\
\square \\
\square \\
\square \\
\square\end{aligned}$ \\
\hline
\end{tabular}

menyelesaikan masalah, (6) tokoh berpindah tempat untuk diadili, (7) terjadilah pertarungan, (8) tokoh meninggal dunia, dan (9) kemudian tokoh menjadi dikenal.

Cerita rakyat Nawangsih dalam menganalisis fungsinya, peneliti menemukan lima fungsi cerita rakyat. Lima fungsi tersebut saling bersinergi dan berguna dalam kehidupan seharihari, mencakup (1) sebagai pendidikan, (2) sebagai pengesahan norma masyarakat, (3) sebagai pembentukan karakter, (4) sebagai nilai budaya masyarakat, dan (5) sebagai alat komunikasi masyarakat.

Nilai adalah konsep yang bernilai tinggi, dipercaya, dan dijadikan dasar oleh individu atau kelompok dalam bertindak. Erat hubungannya jika dihubungkan dengan karakter. Karakter merupakan metode bertindak juga berpikir setiap insan dalam berkomunikasi dalam kehidupan seharihari. Dapat dipahami, bahwa nilai karakter adalah usaha terstruktur dalam menanamkan dan mewujudkan insan yang religius, mandiri, gotong royong, nasionalisme, dan integritas (Permendikbud 2018 mengenai PPK). Folklor Nawangsih setelah dianalisis memiliki nilai karakter religius, mandiri, gotong royong, nasionalisme, dan integritas.

Adapun nilai karakter religius yang terkandung dalam cerita rakyat Nawangsih ditunjukkan dengan adanya beberapa subnilai sebagai berikut.

Tabel 1. Subnilai Religius

\begin{tabular}{|r|l|}
\hline No & \multicolumn{1}{|c|}{ Subnilai Religius } \\
\hline 1 & Beriman dan bertaqwa \\
\hline 2 & Disiplin ibadah \\
\hline 3 & Persahabatan \\
\hline
\end{tabular}

160 | Jurnal Kredo Vol. 4 No. 1 Oktober 2020

\begin{tabular}{|l|l|}
\hline 4 & Ketulusan \\
\hline 5 & Memanfaatkan lingkungan dengan bijak \\
\hline 6 & Kerjasama antar pemeluk agama dan kepercayaan \\
\hline 7 & Percaya diri \\
\hline
\end{tabular}

Sumber: Peneliti

Berdasarkan Permendkibud 2018 tentang PPK bahwa subnilai religius berjumlah 17 subnilai. Sedangkan dalam penelitian ini, peneliti berhasil menganalisis dengan menemukan 7 subnilai dari jumlah keseluruhan. Peneliti menyimpulkan bahwa subnilai religius cukup banyak terkandung dalam cerita rakyat Nawangsih, karena hampir setengah dari jumlah keseluruhan subnilai religius. Berdasarkan pendapat Malita, dkk (2013:2) menyatakan bahwa nilai karakter religius dalam cerita rakyat melukiskan kepercayaaan atau keyakinan atas kekuasaan Tuhan Yang Maha Esa. Sebagai nilai pembentuk yang sangat penting.

Peneliti berpendapat dalam cerita rakyat Nawangsih ini mengandung nilai karakter religius yang bisa tergambar dalam sikap dan tindakan manusia. Sikap dan tindakan yang taat dengan ajaran agama yang dianut serta menjauhi larangan-Nya, bisa ditanamkan dalam pendidikan anak sekolah dasar lewat penguatan pendidikan karakter sejak dini.

Analisis nilai karakter nasionalisme yang terkandung dalam cerita rakyat Nawangsih ditunjukkan dengan adanya beberapa subnilai, sebagai berikut.

Tabel 2. Subnilai Nasionalisme

\begin{tabular}{|c|l|}
\hline No & \multicolumn{1}{|c|}{ Subnilai Nasionalisme } \\
\hline 1 & Apresiasi budaya bangsa sendiri \\
\hline 2 & Menjaga kekayaan budaya bangsa \\
\hline 3 & Menjaga lingkungan \\
\hline 4 & Rela berkorban \\
\hline 5 & Semangat kebangsaan \\
\hline
\end{tabular}




Kredo 4 (2020)
KREDO: Jurnal Ilmiah Bahasa dan Sastra
Terakreditasi Sinta 4 berdasarkan Keputusan Direktorat
Jenderal Penguatan Riset dan Pengembangan,
Kementerian Riset, Teknologi dan Pendidikan Tinggi
Republik Indonesia
Nomor: 23/E/KPT/2019. 08 Agustus 2019
https://jurnal.umk.ac.id/index.php/kredo/index

Berdasarkan Permendikbud 2018 tentang PPK, bahwa subnilai nasionalisme berjumlah 10 subnilai. Sedangkan dalam penelitian ini, peneliti berhasil menganalisis dengan menemukan 5 subnilai dari jumlah keseluruhan. Peneliti menyatakan bahwa subnilai nasionalisme cukup banyak terkandung dalam cerita rakyat Nawangsih, karena setengah dari jumlah keseluruhan subnilai nasionalisme. Berdasarkan pendapat Pramita (2018:21) menyatakan bahwa Pramita juga menemukan nilai karakter nasionalisme dalam penelitiannya terhadap cerita rakyat Petruk Jadi Raja.

Peneliti berpendapat dalam cerita rakyat Nawangsih ini mengandung nilai karakter nasionalisme yang bisa tergambar dalam sikap dan tindakan manusia. Sikap dan tindakan yang semangat membela bangsa dan negara serta mementingkan kepentingan umum, setia melindungi dan menjaga negara, lingkungan, bahasa, dan sosial budaya, bisa ditanamkan dalam pendidikan anak sekolah dasar.

Tabel 3. Subnilai Mandiri

\begin{tabular}{|c|l|}
\hline No & \multicolumn{1}{|c|}{ Subnilai Mandiri } \\
\hline 1 & Kerja keras \\
\hline 2 & Tangguh \\
\hline 3 & Daya juang \\
\hline 4 & Keberanian \\
\hline 5 & Menjadi pembelajar sepanjang hayat \\
\hline
\end{tabular}
Sumber: Peneliti

Berdasarkan Permendikbud 2018 tentang PPK, bahwa subnilai mandiri berjumlah 8 subnilai. Sedangkan dalam penelitian ini, peneliti berhasil menganalisis dengan menemukan 5 subnilai dari jumlah keseluruhan. Peneliti menyatakan bahwa subnilai mandiri cukup banyak terkandung dalam cerita rakyat Nawangsih, karena setengah dari jumlah keseluruhan subnilai mandiri. Adapun kesesuaian hasil penelitian ini dengan kajian relevan diungkapkan oleh Komara (2018) menyatakan bahwa telah menemukan nilai karakter mandiri dalam penelitiannya yang berjudul penguatan pendidikan karakter dan pembelajaran abad 21.

Peneliti berpendapat dalam cerita rakyat Nawangsih ini mengandung nilai karakter mandiri yang bisa tergambar dalam sikap dan tindakan manusia. Sikap dan tindakan yang tidak mudah tergantung dengan orang lain dalam pekerjaan atau mengerjakan sesuatu, bisa ditanamkan dalam pendidikan anak sekolah dasar lewat penguatan pendidikan karakter sejak dini.

Analisis nilai karakter gotong royong yang terkandung dalam cerita rakyat Nawangsih ditunjukkan dengan adanya beberapa subnilai sebagai berikut.

Tabel 4. Subnilai Gotong Royong

\begin{tabular}{|c|l|}
\hline No & \multicolumn{1}{|c|}{ Subnilai Gotong Royong } \\
\hline 1 & Kerja sama \\
\hline 2 & Sikap kerelawanan \\
\hline
\end{tabular}
Sumber: Peneliti

Berdasarkan Permendikbud 2018 tentang PPK, bahwa subnilai gotong royong berjumlah 11 subnilai. Sedangkan dalam penelitian ini, peneliti berhasil menganalisis dengan menemukan 2 subnilai dari jumlah keseluruhan. Peneliti menyatakan bahwa subnilai gotong royong tidak banyak terkandung dalam cerita rakyat Nawangsih, karena tidak ada setengah dari jumlah keseluruhan subnilai gotong royong. Berdasarkan pendapat Junaini, 


Kredo 4 (2020)
KREDO: Jurnal Ilmiah Bahasa dan Sastra
Terakreditasi Sinta 4 berdasarkan Keputusan Direktorat
Jenderal Penguatan Riset dan Pengembangan,
Kementerian Riset, Teknologi dan Pendidikan Tinggi
Republik Indonesia
Nomor: 23/E/KPT/2019. 08 Agustus 2019
https://jurnal.umk.ac.id/index.php/kredo/index

dkk (2017:42) menyatakan bahawa penelitian yang dilakukan terhadap cerita rakyat Seluma juga mengandung nilai karakter gotong royong yang sama dengan cerita rakyat Nawangsih.

Peneliti berpendapat dalam cerita rakyat Nawangsih ini mengandung nilai karakter gotong royong yang bisa tergambar dalam sikap dan tindakan manusia. Sikap dan tindakan dalam mengerjakan tugas ataupun pekerjaan yang dilakukan secara bersama-sama bahu membahu demi kepentingan umum, bisa ditanamkan dalam pendidikan anak sekolah dasar melalui penguatan pendidikan karakter sejak dini.

Analisis nilai karakter integritas yang terkandung dalam cerita rakyat Nawangsih ditunjukkan dengan adanya beberapa subnilai sebagai berikut.

Tabel 5. Subnilai Integritas

\begin{tabular}{|r|l|}
\hline No & \multicolumn{1}{|c|}{ Subnilai Integritas } \\
\hline 1 & Kejujuran \\
\hline 2 & Tanggungjawab \\
\hline 3 & Keteladanan \\
\hline
\end{tabular}

Sumber: Peneliti

Berdasarkan Permendikbud 2018 tentang PPK, bahwa subnilai integritas berjumlah 9 subnilai. Sedangkan dalam penelitian ini, peneliti berhasil menganalisis dengan menemukan 3 subnilai dari jumlah keseluruhan. Peneliti menyatakan bahwa subnilai integritas tidak banyak terkandung dalam cerita rakyat Nawangsih, karena tidak ada setengah dari jumlah keseluruhan subnilai integritas. Adapun kesesuaian hasil penelitian ini dengan kajian relevan diungkapkan oleh Kristanto (2014) yang berpendapat bahwa nilai karakter integritas muncul dan peran cerita rakyat ditanamkan atau diwariskan pada anak akan membekali perkembangan motorik dan psikomotorik serta berkepribadian unggul, yang ditulis dalam penelitiannya yang berjudul pemanfaatan cerita rakyat sebagai penanaman etika untuk pembentukan pendidikan karakter bangsa.

Peneliti berpendapat dalam cerita rakyat Nawangsih ini mengandung nilai karakter integritas yang bisa tergambar dalam sikap dan tindakan manusia. Sikap dan tindakan terhadap segala tugas atau pekerjaan yang dilakukan mencerminkan sosok yang selalu dapat dipercaya dalam tindakan, perkataan, dan pekerjaan, serta memberikan pertolongan kepada siapapun yang membutuhkan, bisa ditanamkan dalam pendidikan anak sekolah dasar lewat penguatan pendidikan karakter sejak dini. Pendidikan karakter ini untuk siswa sekolah dasar usia 7 hingga 13 tahun.

\section{SIMPULAN}

Analisis struktur naratif terhadap cerita rakyat Nawangsih berdasarkan teori Vladimir Propp, ternyata menemukan dua hal yang menarik, yaitu pertama memiliki pola naratif II (larangan) -III (pelanggaran) -VIII (kejahatan) -IX (peristiwa) -XI (keberangkatan) -XII (pemberi) -XIV (penerimaan alat sakti) $-\mathrm{XV}$ (perpindahan tempat) $-\mathrm{XVI}$ (pertarungan) $-\mathrm{XX}$ (kepulangan) $-\mathrm{XXV}$ (tugas berat) -XXVI (penyelesaian) XXVII (pahlawan). Kedua, cerita rakyat Nawangsih ini memiliki struktur naratif yang sederhana, yaitu maksimal hanya memiliki 13 jenis struktur naratif serta 


Kredo 4 (2020)
KREDO: Jurnal Ilmiah Bahasa dan Sastra
Terakreditasi Sinta 4 berdasarkan Keputusan Direktorat
Jenderal Penguatan Riset dan Pengembangan,
Kementerian Riset, Teknologi dan Pendidikan Tinggi
Republik Indonesia
Nomor: 23/E/KPT/2019. 08 Agustus 2019
https://jurnal.umk.ac.id/index.php/kredo/index

tidak mengutamakan cara dalam menyampaikan isi tetapi lebih mengutamakan isi.

Analisis terhadap satu data cerita rakyat, menunjukkan bahwa fungsi dalam cerita rakyat Nawangsih yang dominan, yaitu sarana pendidikan, sarana untuk mengesahkan pranatapranata sosial yang bersifat kolektif yang harus ditaati oleh anggota masyarakat, sarana untuk membangun karakter, sarana untuk pengenalan dan pemahaman terhadap nilai-nilai budaya suatu masyarakat, dan sebagai modal sosial untuk berinteraksi dan berkomunikasi antaranggota atau komunitas suatu masyarakat.

Analisis nilai karkter terhadap cerita rakyat Nawangsih berdasarkan Permendikbud 2018 tentang Penguatan Pendidikan Karakter, ternyata menemukan lima nilai karakter yang terkandung dalam cerita rakyat tersebut, yaitu (1) karakter religius dengan subnilai: beriman dan bertaqwa, disiplin ibadah, persahabatan, ketulusan, memanfaatkan lingkungan dengan bijak, kerjasama antar pemeluk agama dan kepercayaan, dan percaya diri; (2) karakter nasionalisme dengan subnilai: apresiasi budaya bangsa sendiri, menjaga kekayaan budaya bangsa, menjaga lingkungan, rela berkorban, dan semangat kebangsaan; (3) karakter mendiri dengan subnilai: kerja keras, tangguh, daya juang, keberanian, dan menjadi pembelajar sepanjang hayat; (4) karakter gotong royong dengan subnilai: kerja sama dan sikap kerelawanan; serta (5) karakter integritas dengan subnilai: kejujuran, tanggungjawab, dan keteladanan. Peneliti menyimpulkan bahwa nilai karakter yang terkandung dalam cerita rakyat Nawangsih yaitu karakter religius, karakter nasionalisme, karakter mandiri, karakter gotong royong, dan karakter integritas. Nilai karakter yang terkandung dalam ceirta rakyat Nawangsih ini bisa diterapkan ke pendidikan anak sekolah dasar.

Satu cerita rakyat membentuk pribadi dan karakter yang baik untuk anak sekolah dasar. Karakter tokoh dalam cerita rakyat juga bisa dipakai guru sekolah dasar dan orang tua dalam menanamkan karakter anak. Nilai dan aturan yang tersirat dalam cerita rakyat tidak selamanya mudah ditangkap dan dicerna oleh anak. Guru dan orangtua sebaiknya mendampingi dan membimbing anak dalam menikmati cerita rakyat, supaya anak bisa menemukan makna dan karakter tokoh dari cerita rakyat yang telah disimak atau dibacanya.

\section{DAFTAR PUSTAKA}

Alim, et.al. 2020. Implementation of Ethnoscience-based Guided Inquiry Learning on The Scientific Literacy and The Character of Elementary School Stuedents. Journal of Primary Education, 9 (2), 139-147.

Bennett, William J. 1988. Moral Literacy and The Formation of Character. SAGE Journal, 72 (512), 29-34. 


\begin{tabular}{|c|c|c|}
\hline & $\begin{array}{c}\text { Kredo } 4(2020) \\
\text { KREDO: Jurnal Ilmiah Bahasa dan Sastra } \\
\text { Terakreditasi Sinta } 4 \text { berdasarkan Keputusan Direktorat } \\
\text { Jenderal Penguatan Riset dan Pengembangan, } \\
\text { Kementerian Riset, Teknologi dan Pendidikan Tinggi } \\
\text { Republik Indonesia } \\
\text { Nomor: } 23 / \text { E/KPT/2019. 08 Agustus 2019 } \\
\text { https://jurnal.umk.ac.id/index.php/kredo/index }\end{array}$ & $\begin{aligned} \mathrm{KREDO} \\
\square \\
\square \\
\square \\
\square\end{aligned}$ \\
\hline
\end{tabular}

Benninga, Jacques S, et.al. 2003. The Relationship of Character Education Implementation and Academic Achievement in Elementary Schools. Journal of Research Character Education, 1 (1), 19-32.

Cahyaningsih, Riyan Dwi. 2017. Teacher's Perception on Folklores in English Textbook in SMA 1 Bae Kudus. Kredo, 1 (1), 106-119.

Cohen, et.al. 2012. Guilt Proneness and Moral Character. SAGE Journal, 21 (5), 355359.

Danandjaja, James. 1994. Folklor Indonesia Ilmu Gosip, Dongeng, dan lain-lain. Jakarta: PT. Pustaka Utama Grafiti.

Dinas Pariwisata dan Kebudayaan Kabupaten Kudus. 2005. Peninggalan Sejarah dan Purbakala Kabupaten Kudus. Kudus: Disparbud Kudus.

Emzir. 2011. Metodologi Penelitian Pendidikan Kuantitatif \& Kualitatif. Jakarta: Raja Grafindo.

Endraswara, Suwardi. 2009. Metodologi Penelitian Folklor Konsep, Teori, dan Aplikasi. Yogyakarta: Media Pressindo.

Faidah, Citra Nur. 2018. Dekonstruksi Sastra Anak: Mengubah Paradigma Kekerasan dan Seksualitas pada Karya Sastra Anak Indonesia. Kredo, 2 (1), 126-139.

Gelis, Ning. 2017. Pendidikan SD: Rangkuman Makul Perspektif Pendidikan SD, [online], (nienxgeliz.blogspot.com/2017/04/rangkuman-makul-perspektifpendidikan_6.html?m=1, diakses tanggal 19 Januari 2020).

Gusal, La Ode. 2015. Nilai-nilai Pendidikan dalam Cerita Rakyat Sulawesi Tenggara Karya La Ode Sidu. Jurnal Humanika, 3 (15), 121-128.

Hakim, Zainuddin. 2015. Morfologi Cerita Ratu Ular: Model Analisis Vladimir Propp. Sawerigading, 21 (3), 519-527.

Hardiyanti, Dewi, et.al. 2018. Nilai Kearifan Lokal dalam Cerita Rakyat dan Peranannya dalam Membentuk Karakter Anak Didik. Makalah disajikan dalam Seminar Nasional Administrasi Pendidikan dan Manajemen Pendidikan. Prodi Ilmu Pendidikan Bahasa PPs Universitas Negeri Makassar, Hotel Remcy, Makassar, 21 April 2018.

Hasan, Nita Handayani. 2016. Penerapan Teori Vladimir Propp pada Cerita Rakyat Ikan Lompa. Totobuang, 4 (1), 91-102.

164 | Jurnal Kredo Vol. 4 No. 1 Oktober 2020 


Kredo 4 (2020)
KREDO: Jurnal Ilmiah Bahasa dan Sastra
Terakreditasi Sinta 4 berdasarkan Keputusan Direktorat
Jenderal Penguatan Riset dan Pengembangan,
Kementerian Riset, Teknologi dan Pendidikan Tinggi
Republik Indonesia
Nomor: 23/E/KPT/2019. 08 Agustus 2019
https://jurnal.umk.ac.id/index.php/kredo/index

Indiarti, Wiwin. 2017. Nilai-nilai Pembentuk Karakter dalam Cerita Rakyat Asal-usul Watu Dodol. Jentera, 6 (1), 26-41.

Junaini, Esma, dkk. 2017. Analisis Nilai Pendidikan Karakter dalam Cerita Rakyat Seluma. Jurnal Korpus, 1 (1), 39-43.

Kanzunnudin, Mohammad. 2012. Peran Sastra dalam Pendidikan Karakter. Makalah disajikan dalam Seminar Nasional Pendidikan: Pendidikan untuk Kejayaan Bangsa. Universitas Sanata Dharma, Yogyakarta, 26 Juni 2012.

2017. Menggali Nilai dan Fungsi Cerita Rakyat Sultan Hadirin dan Masjid Wali At-Taqwa Loram Kudus. Kredo, 1 (1), 1-17.

2020. Cerita Lisan Dua Orang Sunan Beradu Jago dalam Kajian Struktural dan Fungsi Alan Dundes. Kredo, 3 (2), 235-248.

Kesuma, Dharma, et.al. 2013. Pendidikan Karakter Kajian Teori dan Praktik di Sekolah. Bandung: PT. Remaja Rosdakarya.

Komara, Endang. 2018. Penguatan Pendidikan Karakter dan Pembelajaran Abad 21. Sipatahoenan, 2 (1), 17-26.

Kristanto, M. 2014. Pemanfaatan Cerita Rakyat sebagai Penanaman Etika untuk Membentuk Pendidikan Karakter Bangsa. Mimbar Sekolah Dasar, 1 (1), 59-64.

Lestari, Ummu Fatimah Ria. 2015. Morfologi Cerita Rakyat Arso Watuwe: Sebuah Analisis Naratologi Vladimir Propp. Meta Sastra, 8 (1), 139-154.

Malita, Nur, dkk. 2013. Nilai-nilai Pendidikan Karakter dalam Cerita Rakyat Malang. Artikel Hasil Penelitian.

Maryatin. 2018. Studi Komparasi Hasil Mendengarkan Cerita Rakyat Timun Mas dengan Menggunakan Media Audio dan Tidak Menggunakan Media Non Audio di SDN 033 Balikpapan. Stilistika, 3 (1), 19-26.

Maulina, Yeni. 2014. Cerita Rakyat Asal-usul Pulau Halang: Analisis Fungsi Vladimir Propp. Madah, 5 (1), 105-114.

Maunah, Binti. 2015. Implementasi Pendidikan Karakter dalam Pembentukan Kepribadian Holistik Siswa. Jurnal Pendidikan Karakter, 5 (1), 90-101.

Mujiyanto, Yan, et.al. 2010. Pengantar Ilmu Budaya. Yogyakarta: Pelangi Publishing. 


Kredo 4 (2020)
KREDO: Jurnal Ilmiah Bahasa dan Sastra
Terakreditasi Sinta 4 berdasarkan Keputusan Direktorat
Jenderal Penguatan Riset dan Pengembangan,
Kementerian Riset, Teknologi dan Pendidikan Tinggi
Republik Indonesia
Nomor: 23/E/KPT/2019. 08 Agustus 2019
https://jurnal.umk.ac.id/index.php/kredo/index

Mulyasa. 2013. Manajemen Pendidikan Karakter. Jakarta: PT. Bumi Aksara.

Murniyetti, et.al. 2016. Pelaksanaan Pendidikan Karakter terhadap Siswa Sekolah Dasar. Jurnal Pendidikan Karakter, 4 (2), 156-166.

Muslich, Masnur. 2011. Pendidikan Karakter Menjawab Tantangan Krisis Muldimensional. Jakarta: PT. Bumi Aksara.

Muttaqin, Muhammad Fauzan, et.al. 2018. The Implementation Main Values of Character Education Reinforcement in Elementary School. Journal of Primary Education, 7 (11), 103-112.

Nazarudin, Andri. 2013. Rumah Bangsa Foundation: Fungsi Tujuan dan Karakteristik Pendidikan SD, [online], (www.rumahbangsa.net/2013/07/fungsi-tujuan-dankarakteristik.html?m=1, diakses tanggal 19 Januari 2020).

Permendikbud Nomor 20 Tahun 2018 Tentang Penguatan Pendidikan Karakter pada Satuan Pendidikan Formal.

Pramita, Fatma. 2018. Analisis Nilai Karakter dalam Cerita Petruk jadi Raja Karya Suyadi sebagai Bahan Penguatan Pendidikan Karakter (PPK) di SDN Pandeanlamper 05 Semarang. Jurnal Guru Kita, 2 (2), 16-22.

Rahayu, Memori Gusti, et.al. 2018. Analisis Pesan Moral dalam Cerita Rakyat Kluet di Kabupaten Aceh Selatan. Jurnal Ilmiah Mahasiswa Jurusan PBSI, 3 (1), 11-20.

Ramadhan, Hutama Hari, et.al. 2016. Analisis Tema, Amanat, dan Fungsi Cerita dalam Kumpulan Cerita Rakyat Kalantika. Jurnal Pendidikan dan Pembelajaran Khatulistiwa, 5 (15), 1-15.

Ramitha, et.al. 2015. Aplikasi Cerita Rakyat (Floktale) Nusantara Berbasis Android. Jurnal Sains dan Teknologi, 1 (1), 49-54.

Rohmat, Lutfi Irawan. 2019. Kajian Antropologi Sastra dalam Cerita Rakyat Kabupaten Banyuwangi pada Masyarakat Using. Kredo, 3 (1), 83-93.

Roysa, Mila. 2017. Analisis Buku Bacaan Anak "Belajar Sambil Beternak Ayam" Berdasarkan Pendekatan Struktural. Kredo, 1 (1), 18-30.

Rubiyanto, Rubino. 2011. Metode Penelitian Pendidikan. Solobaru: Qinant.

Samani, Muchlas, et.al. 2012. Konsep dan Model Pendidikan Karakter. Bandung: PT. Remaja Rosdakarya.

166 | Jurnal Kredo Vol. 4 No. 1 Oktober 2020 


\begin{tabular}{|c|c|c|} 
Kredo 4 (2020) \\
KREDO: Jurnal Ilmiah Bahasa dan Sastra \\
Terakreditasi Sinta 4 berdasarkan Keputusan Direktorat \\
Jenderal Penguatan Riset dan Pengembangan, \\
Kementerian Riset, Teknologi dan Pendidikan Tinggi \\
Republik Indonesia \\
Nomor: 23/E/KPT/2019. 08 Agustus 2019 \\
https://jurnal.umk.ac.id/index.php/kredo/index
\end{tabular}

Setyosari Punaji. 2020. Metode Penelitian Pendidikan dan Pengembangan. Jakarta: Prenada Media Grup.

Sugiyono. 2016. Metode Penelitian Pendidikan Pendekatan Kuantitatif, Kualitatif, dan $R \& D$. Bandung: Alfabeta.

Suhaimi, et.al. 2014. Struktur dan Fungsi Cerita Rakyat Pak Alui Sastra Lisan Masyarakat Melayu Sanggau Kabupaten Kudus. Jurnal Pendidikan dan Pembelajaran, 3 (1), 1-12.

Susanti, Rosa. 2013. Penerapan Pendidikan Karakter di Kalangan Mahasiswa. Jurnal At-Ta'lim, 1 (6), 480-487.

Vansina, Jan. 2014. Oral Tradition as History. Terjemahan Astrid Reza bkk. Yogyakarta: Ombak. 